\title{
東北地方太平洋沖地震時における防波堤による浸水低減効果検討

\author{
Breakwater Effects on Tsunami Inundation Reduction in the 2011 off the Pacific Coast \\ of Tohoku Earthquake
}

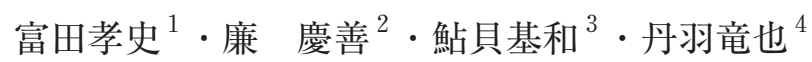 \\ Takashi TOMITA, Gyeong-Seon YEOM, Motokazu AYUGAI and Tatsuya NIWA
}

\begin{abstract}
The effect of breakwater on reduction of tsunami inundation is investigated for the tsunami caused by the 2011 off the Pacific coast of Tohoku Earthquake. Numerical simulations are conducted in the Port of Kamaishi and Port of Ofunato and Port of Soma in which bay-mouth breakwaters and offshore breakwater are installed. It is confirmed that the baymouth breakwater in Kamaishi and offshore breakwater in Soma reduced the area of tsunami inundation and its height, although they were damaged by the tsunami. The reason why they reduced tsunami impacts is that caissons remain partly and mostly. In addition, the numerical simulation indicates that the breakwater mound has the effect on reduction of tsunami intrusion for the bay-mouth breakwater in Ofunato.
\end{abstract}

\section{1.はじめに}

2011 年3月 11 日に発生した東北地方太平洋沖地震およ び津波は, 18,915名（2012年5月 2 日警察庁公告資料より） の死者・行方不明者をもたらした。特に沿岸部での津波 による被害が激しかった。津波による浸水面積は，国土 地理院によると青森県 $24 \mathrm{~km}^{2}$, 岩手県 $58 \mathrm{~km}^{2}$, 福島県 $112 \mathrm{~km}^{2}$, 茨城県 $23 \mathrm{~km}^{2}$, 千葉県 $17 \mathrm{~km}^{2}$ であり, 平野部が 多い宮城県では $327 \mathrm{~km}^{2}$ に及んだ。この浸水面積に比例し て宮城県の人的・物的被害は全国総被害の半分以上を占 めた。浸水被害を低減する有効な対策は, 防波堤などの ハードウェア的な対策であり, 今回の津波にもその効果 が一部報告されている（高橋ら，2011）.

本研究では, 数值シミュレーションを実施して, 東北 地方太平洋沖地震津波に対する釜石港および大船渡港の 湾口防波堤，および相馬港の沖防波堤の効果を検討する.

\section{2. 対象港湾の防波堤の損傷}

\section{（1）釜石港}

釜石港の湾口防波堤は，1978年から 2009年3月まで約 30 年をかけて完成し, 明治三陸地震津波および昭和三陸 地震津波を勘案して設計され, 防波堤位置での設計津波 高は $4.8 \mathrm{~m}$ であった. しかし, 防波堤の安定性は波浪（周 期 13 秒，波高 $13.3 \mathrm{~m}$ ）により決まっている.

\begin{tabular}{|c|c|c|}
\hline 1 正会員 & 博 (工) & (独法) 港湾空港技術研究所 アジア・太 \\
\hline 2 正会員 & 博 (工) & $\begin{array}{l}\text { 平洋沿岸防災研究センター 副センター } \\
\text { (独法) 港湾空港技術研究所 アジア. } \\
\text { 太平洋沿岸防災研究センター 研究官 }\end{array}$ \\
\hline 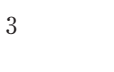 & & $\begin{array}{l}\text { 東北地方整備局 港湾空港部 港湾計画 } \\
\text { 課 海岸·環境係長 }\end{array}$ \\
\hline 4 正会員 & 修 (工) & $\begin{array}{l}\text { (独法) 港湾空港技術研究所 アジア・太 } \\
\text { 平洋沿岸防災研究センター 依頼研修員 } \\
\text { (パシフイックコンサルンツ株式会社) }\end{array}$ \\
\hline
\end{tabular}

図-1は, 東北地方太平洋沖地震津波後に実施された湾 口防波堤周辺のナローマルチビーム測深による海底地形 図である. 図中の白枠は震災後のケーソンの位置を示し ている. 東北地方太平洋沖地震津波の作用により, 北堤 (同図の左側) ではケーソンが所々移動し歯抜け状態に なり, 南堤 (同図の右側) では開口部側の半分は移動し ていないが陸側の半分は港内側に移動した. なお, 後述 する数值計算によると, 防波堤前面に沿った最大津波高 は11 13m程度である。

\section{（2）大船渡港}

大船渡湾は，1960年南米チリから伝播した津波により 大きな被害を受けた。それを契機に，1963年から4年か けて湾口防波堤が建設された。防波堤位置での設計津波 波高は $6.0 \mathrm{~m}$ であった.

図-2に東北地方太平洋沖地震津波後に実施された湾口 防波堤周辺のナローマルチビーム測深による海底地形図

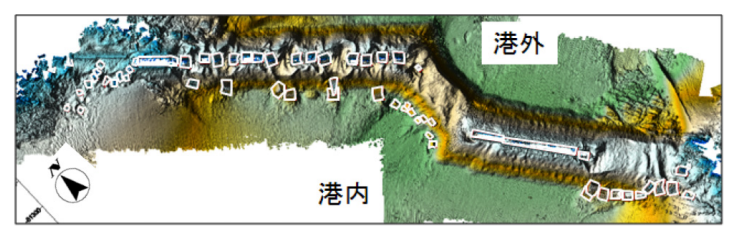

図-1 東北地方太平洋沖地震津波後の釜石湾口防波堤周辺の 海底地形図

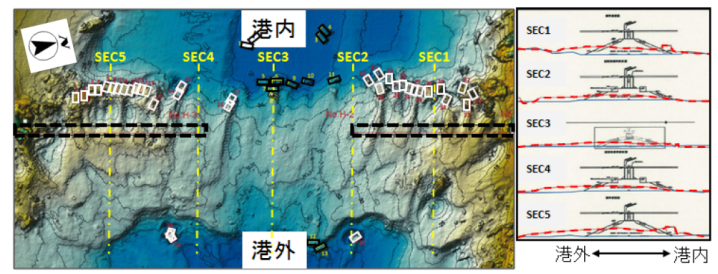

図-2 東北地方太平洋沖地震津波後の大船渡湾口防波堤周辺 の海底地形図 


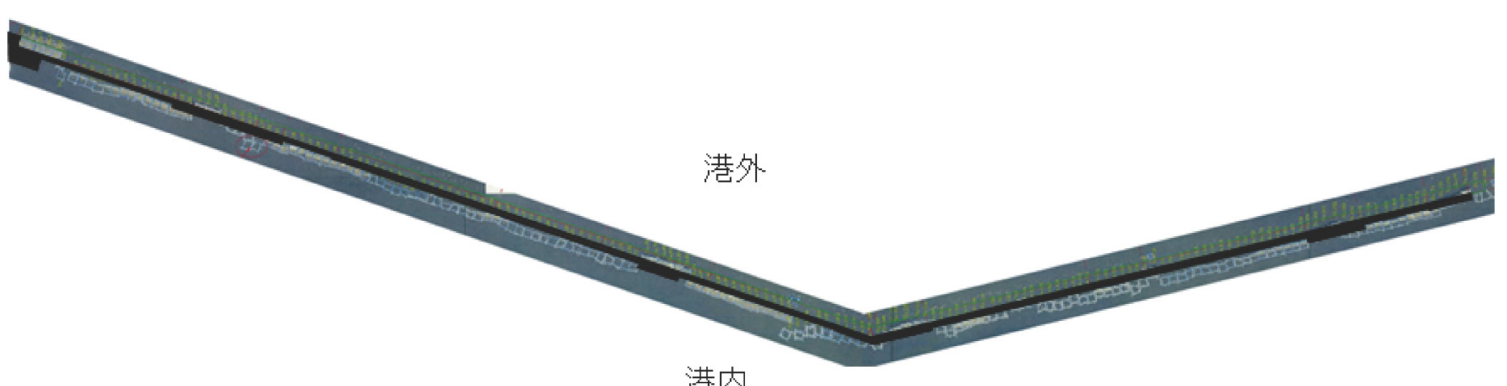

港内

写真-1 東北地方太平洋沖地震津波後の相馬港沖防波堤

を示す．左図における中央部の黑点線枠はケーソンの元 の位置, 白実線染は震災後のケーソンの位置, 黒実線枠 は震災後の開口部潜堤の鋼セルの位置であり，右図にお ける点線は震災後のマウンドの形状を示す，全てのケー ソンがマウンドから転落するとともに，ほとんどのマウ ンドもその高さの半分にまで低くなって，港外側に広が っている，な㧍，今回実施した数值計算によると，防波 堤前面に沿った最大津波高は12 13m程度である.

\section{（3）相馬港}

相馬港の沖防防波堤は，東北地方太平洋沖地震津波に よって，全181函のケーソンのうち 159 函が傾斜，転倒 または移動した。しかし，写真-1に示すように，ヶーソ ンの移動範囲は狭く, マウンド周辺に留まった。同写真 の黒い部分が被災前の港内側マウンド幅, 白枠は移動し たケーソンの位置である.

\section{3. 東北地方太平洋沖地震津波の数値計算}

防波堤の津波に対する効果を検討するために，港湾空 港技術研究所が開発した高潮津波シミュレータSTOC （富田・杮沼，2005）のうちの静水圧流動モデル STOCMLを使用して東北地方太平洋沖地震津波を対象に津波 の伝播・浸水計算を実施した。

計算負荷を勘案し, 震源域を包含する最外側領域から 計算格子サイズを徐々に小さくするネスティング手法を 用いた，港湾域の全てを含む最内側領域では航空レーザ 一測量成果，海図，港湾計画図および施設台帳などに基 づいて作成した $5 \mathrm{~m}$ 格子の水深，地形㧍よび構造物デー 夕を使用した。

初期波源の計算では, 藤井・佐竹の断層パラメー夕 Ver.4.0（国土技術政策総合研究所・建築研究所合同建築 物地震対応検討会議，2011）を基本としたが，釜石港お よび大船渡港の計算ではそれぞれの港湾の沖合にある岩 手県南部沖㧍よび宮城県北部沖のGPS 波浪計によって観 測された津波波形，特に最大の津波高になった第 1 波目 の津波高に合うように滑り量を 1.5 倍した。図-3に岩手県 南部沖㧍よび宮城県北部沖の GPS 波浪計設置位置におけ

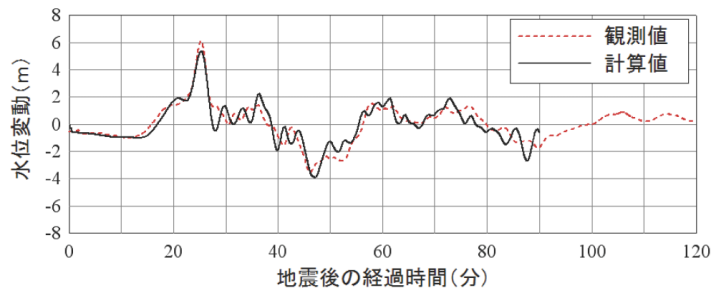

(a) 岩手県南部沖

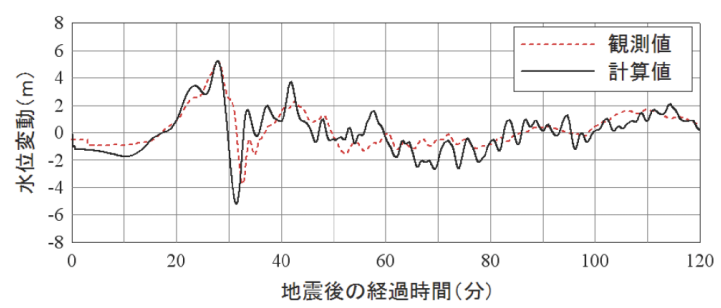

(b) 宮城県北部沖

図-3ＧPS 波浪計の観測結果と計算結果の比較

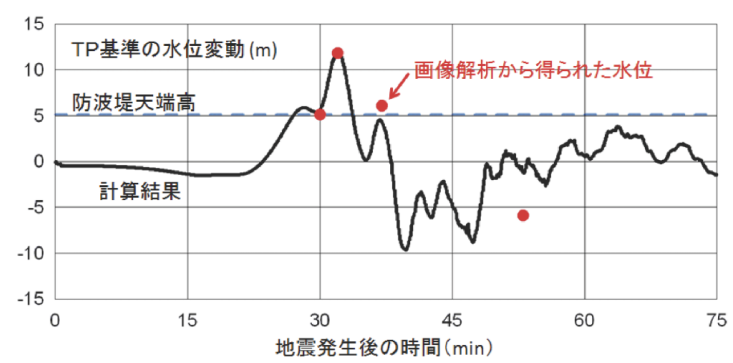

図-4 釜石港湾口防波堤開口部付近の水位変動

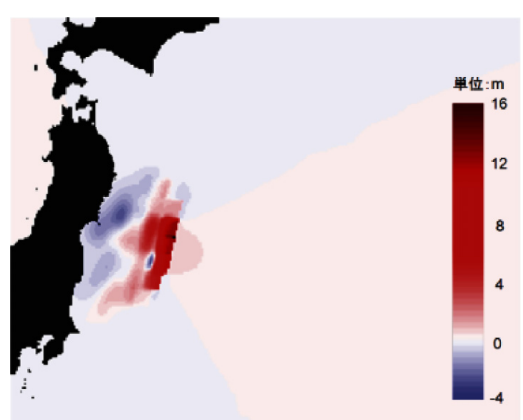

図-5 滑り量を 1.5 倍した初期波源分布 


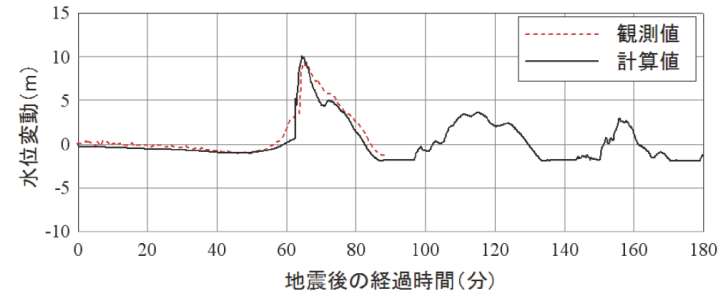

図-6 相馬港験潮所の観測値と計算值の比較

る波形の観測值と計算値を示す。計算結果は観測結果に よく一致している，さらに，図-4に釜石港の湾口防波堤 の開口部付近を撮影した写真（海上保安庁提供）および ビデオ映像（国土交通省東北地方整備局釜石港湾事務所 撮影㧍よび海上保安庁撮影) から解析した海水位と計算 から得られた津波波形を比較する。同図より計算結果は 実際の水位変動をよく再現していることが確認された. 初期波源分布の一例として, 滑り量を 1.5 倍した最外側 領域の初期水位分布を図-5に示す.

相馬港の計算では，宮城県中部沖および福島県沖の二 つの GPS 波浪計の観測值および「東北地方太平洋沖地震 津波合同調查グループ (http://www.coastal.jp/ttjt/)」によ る相馬港周辺 15 地点の津波痕跡高に合うように滑り量を 補正して設定した。滑り量を 1.0 倍, 1.1 倍および 1.2 倍し た場合，相田による幾何平均 $\mathrm{K} は 0.96 ， 0.91$ および 0.86 であり, 滑り量 1.0 倍の場合が波源断層パラメー夕の目 安 $0.95<\mathrm{K}<1.05$ を満たした。幾何標準偏差 $\kappa は 1.49,1.49$ および 1.46 であり, どの場合も目安 $\kappa 1.45$ を満たすこと ができなかったが, 滑り量を 0.9 倍に小さくすると, 浸 水範囲が調查結果をさらに過小評価することになった. 以上のような検討を踏まえて, 工学的な判断により, 滑 り量を 1.0 倍とした。相馬港内の験潮所で観測された水 位変動と数值計算結果の比較を図-6に示す．同図より, 計算值と観測值の良好な一致がみられた。

釜石港および大船渡港の湾口防波堤および相馬港の沖 防波堤に関しては，現況（防波堤が破壊しない完成形の 条件), 防波堤破壊後(防波堤が最初から破壊している 状態に津波が来襲する条件）および防波堤建設前（防波 堤が無い条件）の条件で数值計算を実施した。なお，大 船渡港では防波堤マウンド（ケーソンがなくマウンドの みがある状態に津波が来襲する条件）とマウンド半分 (ケーソンがなくマウンドが半分の高さの状態に津波が 来襲する条件；破壊後）の条件での計算も行っている. また, 各計算では津波来襲時の天文潮位および対象港湾 の地盤沈下量を考慮している。

\section{4. 防波堤による浸水低減効果の検討}

\section{（1）釜石港}

図-7は，釜石湾口防波堤の現況，破壊後（図-1参照） 抢よび建設前のケースでの最大浸水高㧍よび津波高分布 図である．数值計算による浸水面積は, 現況が $2.65 \mathrm{~km}^{2}$ (全浸水面積に対する浸水深 $2 \mathrm{~m}$ 以上の面積の割合： $61.2 \%)$ ，破壞後が $4.16 \mathrm{~km}^{2} （ 90.0 \% ）$ および建設前が $4.43 \mathrm{~km}^{2}(91.1 \%)$ であり，湾口防波堤の存在による浸水 域の低減効果が確認できる。浸水高の計算值を測量され た痕跡高と比較すると, 現況のケースでは少し低くなっ ているが, 他のケースに比べると痕跡值に最も近い值と なっている. 一方, 破壞後のケースでは計算值が高くな っている. 津波来襲時に撮影された釜石港のビデオ映像 からは第 1 波の引き波の際に湾口防波堤が破壊している ことが確認できたので, 数值計算における比較を勘案す ると, 第 1 波目の押し波のピーク過ぎあたりまでは湾口 防波堤は粘り強く津波に耐え，それに上り港内の津波高 や浸水域の低減が発揮されたと推察される。防波堤がな い場合では, 湾奥部海岸線近傍の浸水高は $15 \mathrm{~m}$ 程度にな

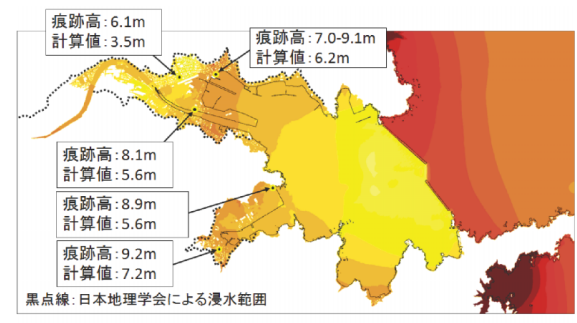

(a) 現況

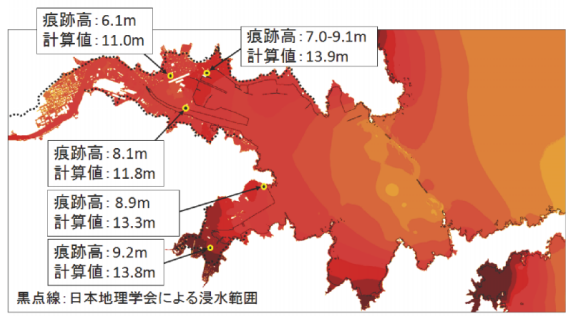

(b) 破壊後

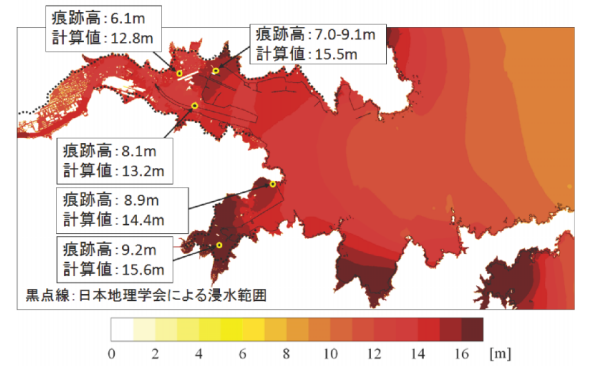

(c) 建設前

図-7 釜石港の最大浸水高および津波高分布（図-1参照） 


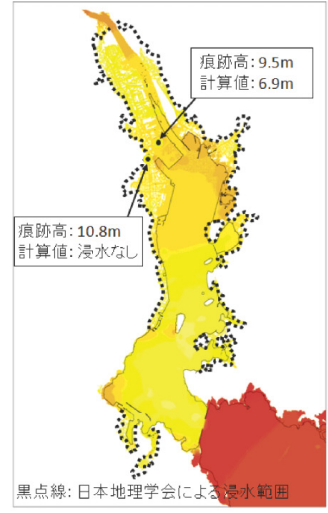

(a) 現況

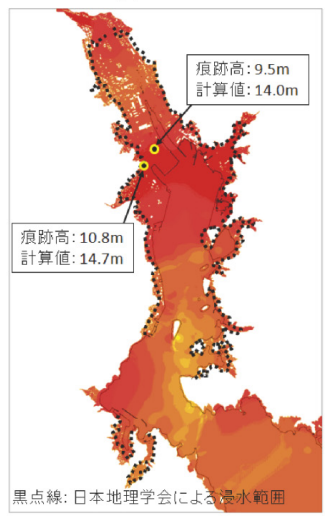

(c) 破壊後（マウンドの半分）

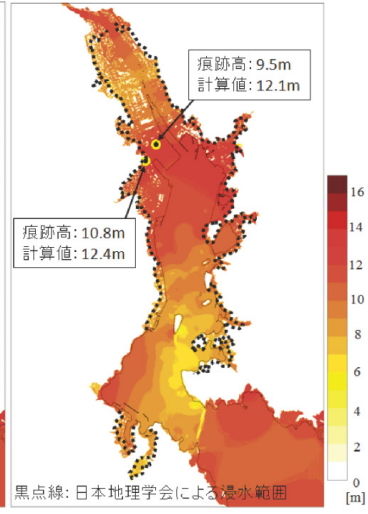

(b) 防波堤マウンド

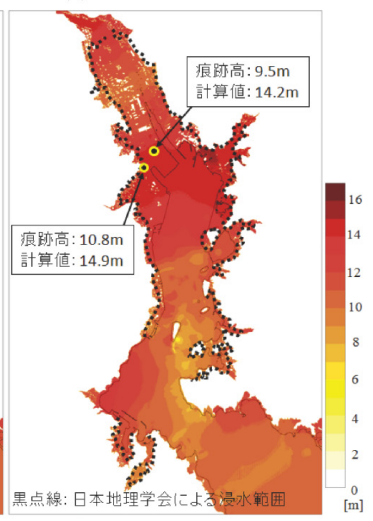

(d) 建設前

図-8 大船渡港の最大浸水高および津波高分布（図-2参照）

るのに対し，実際の浸水高は $9 \mathrm{~m}$ 程度になっている。す なわち，損傷してはいるが防波堤があることによる遮蔽 性によって浸水高を約4割程度低隇している.

\section{（2）大船渡港}

図-8に大船渡港の湾口防波堤の現況，防波堤マウンド, 破壊後（図-2参照）および建設前のケースの最大浸水高 および津波高分布を示す．数值計算から得られた浸水面 積は，現況が $3.74 \mathrm{~km}^{2}$ （全浸水面積に対する浸水深 $2 \mathrm{~m}$ 以 上の面積の割合： $74.9 \%)$, 防波堤マウンドが $5.46 \mathrm{~km}^{2}$ (86.4\%)，破壊後が $6.15 \mathrm{~km}^{2} （ 89.1 \%$ ）および建設前が $6.21 \mathrm{~km}^{2}(89.2 \%)$ であり，釜石港と同様に湾口防波堤の 存在により浸水範囲が狭くなっており，同図から浸水高 の低減も確認できる。

防波堤マウンドのケースは建設前のケースに比べて浸 水範囲や津波高の低減が認められるが，測量された痕跡 高よりも高い。さらに，図-2からは，移動したケーソン は港内側にあり，マウンドは港外側に広がっている。こ れらのことから，大船渡港の湾口防波堤は，第 1 波目の 押し波の作用により港内側にケーソンが移動・転倒した 後に残ったマウンドにより若干の遮蔽効果があって津波

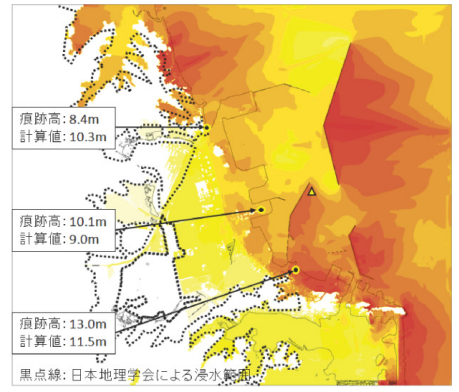

(a) 現況

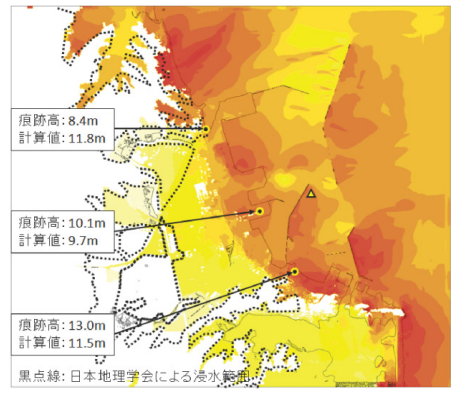

(b) 破壊後

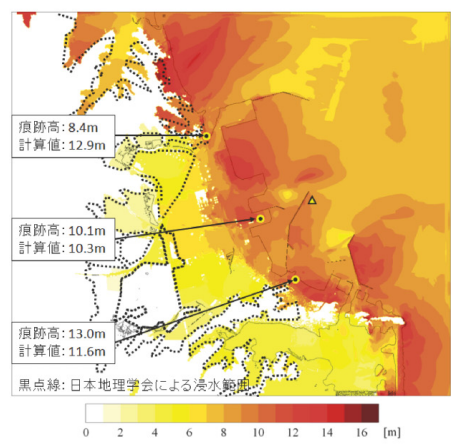

(c) 建設前

図-9 相馬港の最大浸水高抢よび津波高分布（写真-1参照）

による流入量が低減したと考えられる。このことは，ケ ーソンが移動したとしても，マウンドの天端を維持でき る粘り強い構造とすることで港内への津波の侵入を低減 し，浸水などの被害を軽減できることを示唆するもので ある。

\section{（3）相馬港}

相馬港の沖防波堤の現況，破壊後（写真-1参照）およ び建設前のケースの最大浸水高掞よび津波高分布を図-9 に示す。数值計算から得られた浸水面積は, 現況が $5.81 \mathrm{~km}^{2}$ (全浸水面積に対する浸水深 $2 \mathrm{~m}$ 以上の面積の割 合： $55.1 \%)$ ，破壊後が6.66 $\mathrm{km}^{2}(63.5 \%)$ および建設前が $7.13 \mathrm{~km}^{2}(70.3 \%)$ であり，破壊後のケースにおいても浸 水低減効果が確認できる。この低減効果は，写真-1のよ うに多くのケーソンが津波により転倒または移動したが 
マウンド周辺に留まったことから生じたと考えられる.

第 1 波来襲時の防波堤周辺の水位および流れ場の変化 を図-10に示す。沖防波堤の南端を回折した津波は，そ の背後にある南防波堤によってそのほとんどが反射され

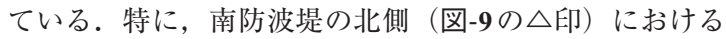
最大津波高は，現況のケースでは $10.0 \mathrm{~m}$, 破壊後のケー スでは $9.8 \mathrm{~m}$ および建設前のケースでは $9.3 \mathrm{~m}$ であり, 沖 防波堤の回折波の影響を受けて現況のケースにおいて津 波高が高くなっている.このように沖防波堤によって局 所的に水位が高くなるが，南防波堤の存在によってそれ が陸上に及ぼす影響が低減され浸水高や浸水範囲が低減 した。これは, 沖防波堤と南防波堤によって多重防護さ れていたことを示す。

\section{5. おわりに}

本研究では，2011年東北地方太平洋沖地震津波により 損傷を受けた釜石湾口防波堤，大船渡湾口防波堤および 相馬港沖防波堤を対象として，それらの津波に及ぼす影 響を数值計算により検討した。計算は，主に防波堤が津 波により被災しない場合（現況のケース），津波来襲前 から防波堤が被災していた場合（破壊後のケース）およ び防波堤が存在しない場合（防波堤建設前のケース）に ついて実施した。

各港湾において, 防波堤の存在により浸水範囲および 浸水高が低減され, 損傷した防波堤であっても, 完全に 破壊されずに一部が残ったことにより建設前と比べて一 定の浸水低減効果があることが確認できた。

また，大船渡港ではほとんどのケーソンが移動しても， マウンド高を維持することにより津波低減効果が発揮さ れる可能性があることを示唆した.

相馬港では，沖防波堤による津波の低減だけではなく， 港内の第 2 線防波堤による港内津波低減効果が確認され, 多重防御の重要性を明らかにした。

津波減災には，損傷しても完全に崩壊しないように粘 り強さを持たせた防波堤等の防護施設を設置することや 一般防波堤であっても多重で防御することが重要である と考えられる。

謝辞：本研究の実施にあたり，国土交通省東北地方整備 局仙台港湾空港技術調查事務所から水深・地形データお よび防波堤損傷に関する情報の提供を受けた。また，詳 細な地形デー夕作成において国土地理院地理調査部から 海岸における $3 \mathrm{D}$ 電子地図に関する資料の提供を受けた. ここに深甚なる謝意を表する。

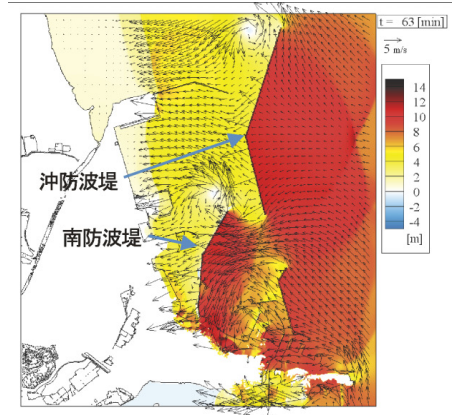

(a) 現況

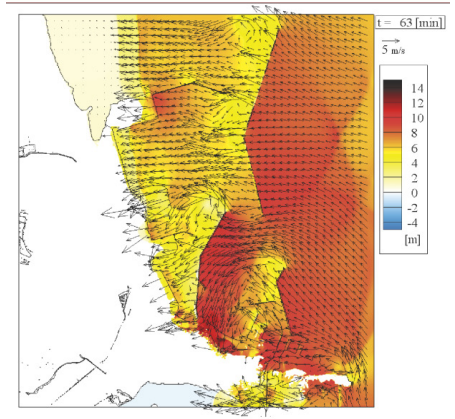

(b) 破壞後

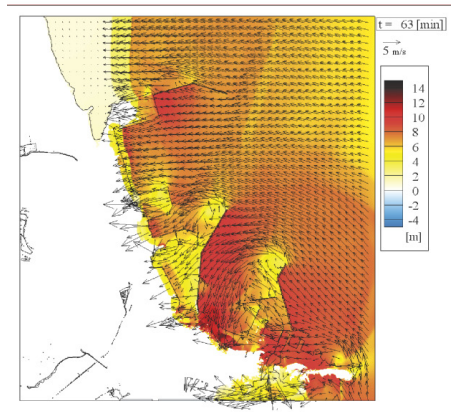

(c) 建設前

図-10 相馬港における津波の侵入状況（写真-1参照）

参 考 文 献

国土技術政策総合研究所 - 建築研究所合同建築物地震対応検 討会議（2011）：平成23年（2011年）東北地方太平洋沖 地震調査研究 (速報) (東日本大震災), 建築研究資料, 第 132 号.

高橋重雄 - 戸田和彦 - 菊池喜昭 - 菅野高弘 - 栗山善昭 - 山㠃 浩之・長尾 毅・下迫健一郎・根木貴史・菅野甚活・富 田孝史・河合弘泰・中川康之・野津 厚 - 岡本 修 ·鈴 木高二朗・森川嘉之・有川太郎・岩波光保・水谷崇亮・ 小濱英司 - 山路 徹 - 熊谷兼太郎 - 辰巳大介・鷲崎 誠・泉山拓也 ·関 克己 - 廉 慶善 - 竹信正寛 - 加島寛 章 - 伴野雅之. 福永勇介 - 作中淳一郎 - 渡邊祐二 （2011）：2011年東日本大震災による港湾・海岸・空港の 地震・津波被害に関する調查速報, 港湾空港技術研究所 資料, No.1231.

富田孝史・柿沼太郎（2005）：海水流動の3次元性を考慮した高 潮・津波数值シミュレータSTOCの開発と津波解析への適 用, 港湾空港技術研究所報告, 第44券, 第2号, pp.83-98. 